\title{
A survey on gastro-intestinal helminth parasites of Channa species at Kanchanrup Municipality, Saptari, Nepal
}

\author{
Jay Narayan Shrestha ${ }^{1}$, Ganesh Bahadur Thapa ${ }^{2}$ 凶, and Samjhana Shrestha ${ }^{1}$ \\ ${ }^{1}$ Department of Zoology, Post Graduate Campus, Tribhuvan University, Biratnagar, Nepal \\ ${ }^{2}$ Natural History Museum, Tribhuvan University, Swayambhu, Kathmandu, Nepal \\ ganeshbdr13@gmail.com
}

\begin{abstract}
A survey on gastro-intestinal helminth parasites of Channa species was done from the fish markets of Kanchanrup municipality and surrounding rivers and ponds with the help of local fishermen from May 2017 to April 2018. The experimental fishes were carried in the laboratory of Post Graduate Campus, Biratnagar. The visceral masses of the fishes were removed and examined under microscope by simple wet mount preparation for occurrence of various helminth parasites. Data were analyzed using SPSS version 16. C. orientalis ( $\mathrm{n}=200)$ was infected by nematodes (Capillaria pterophylli), trematodes (Gonocerca physidis and Genarchopsis goppo) and cestodes (Senga sp.) giving prevalence of $87.5 \%$. Similarly, $C$. striatus $(\mathrm{n}=225)$ was infected by nematodes (Camallanus intestinalis and Neocamellanus sp.), cestodes (Bothriocephalus sp.) and acanthacephalan (Pallisentis ophiocephali) with prevalence of infection $85.33 \%$. The total multiple infection number was 131(74.9\%) found in C. orientalis. Channa spp. were heavily loaded by gastro-intestinal helminth parasites which may give rise to a health threat of zoonotic transmission to consumers. Therefore, immediate development of effective control measures and an application of good nourishment practice urgently needed to lower the helminth infection to fishes.
\end{abstract}

Keyword: snake head fish, Gonocerca phycidis, multiple infection, eastern Nepal 


\section{INTRODUCTION}

Fishes are high quality, cheap and easily available source of animal protein, mainly for human, livestock and fishery itself. About $25 \%$ of the world's protein is contributed alone by fish and shellfish. Their meat is easily digestible containing most of animal proteins, minerals (phosphorus, magnesium, iron, copper, and zinc), vitamins (A\&D) and unsaturated fatty acid including Omega-3. Among the various fish species, Channa sp. (the snakehead fishes), an important food for Nepalese people, are predatory freshwater teleosts of family Chhanidae inhabiting in streams, reservoirs, lakes, swamps, paddy fields, ponds and lowland stretches of rivers distributed across Bangladesh, west Bengal and Assam of India, Bhutan, Myanmar, Pakistan, Thailand and Sri Lanka including most of the Nepalese riverine system such as Koshi,Gandaki, Karnali , Narayani, Bagmati, Trisuli, etc.

The predatory fish species promote a greater diversity and abundance of larval helminths than herbivorous and planktivorous species (Luque \& Poulin, 2004). About $80 \%$ infection of warm water, fishes is caused by parasites (Eissa, 2002). Channa species are resistance to the parasites but the adverse conditions like water pollution, temperature fluctuation, absence of suitable foods, low oxygen dissolves and others adverse conditions permit them to become susceptible to the various helminth parasitic infections (Sharma, 2012). Viruses, bacteria and fungi are other agents that cause secondary infection in fishes (Khalil \& Polling, 1997). Khurshid \& Ahmad (2012) found that locality of its habitat also determines the kinds and acuteness of helminth infections in fishes. Helminth infections also depend on host species, age and immunity of fish, helminth species and its intensity. The helminth parasites are detrimental to fish health either through fatality and distress along with reduction in host's weight and reproduction (Rohde, 1993) or through interference in nutrition, metabolism and secretory function of the alimentary canal, damaging the nervous system (Markov, 1961) leading it to gastrointestinal abrasions and facilitation of invasion by opportunistic microorganisms which drive towards an ultimate economic loss.

The snakehead fishes (Channa species) contribute to an important freshwater fishery and have great demand in Terai, Nepal because of their delicious flesh, high protein content and the presence of little bones. In spite of helminth's key role in parasitic 
infections on fishes, studies on biodiversity of metazoan parasites are sparse such as Euclinostomum multicaecum, E. heterostomum, Genarchopsis goppo, Allocreadium handiai, Senga ophiocephalina, Porrocaecum sp., Ascaridia sp., Contracaecum sp. and Pallisentis ophiocephali in Channa punctatus (Farzana et al., 2019) and Acanthocephala (Pallisentis sp.), Trematode (Allocredium sp. and Genarchopsis sp.), Nematode (Procamallanus sp. and Neocamallanus sp.) and Cestode (Senga sp.) in Channa species (Gautam et al., 2018). Furthermore, few works have been carried out on helminth parasite of fishes in Nepal by Gupta (1996), Khanal (2003) and Yadav (2017). Some researchers in the same field from other countries are Chowdhury \& Hossain (2015), Singha et al. (2015), Ningthoukhongjam et al. (2015), Gupta et al. (2016), Kundu \& Bhuiyan (2016), Mangolsana et al. (2016), Gautam et al. (2018) and Farzana et al. (2019). Therefore, despite its detrimental effect on fish health and economy in fishery industry, only few works so far have been carried out on burden of helminth parasites in the gastro-intestinal tract of Channa species. Therefore aim of the present study was to detect the helminth parasites of Channa orientalis (Bloch \& Schneider, 1801) and C. striatus (Bloch, 1793) in Saptari district, eastern Nepal.

\section{Study area}

The study was carried out in Kanchanrup Municipality $\left(26.64^{\circ} \mathrm{N}\right.$ and $\left.86.91^{\circ} \mathrm{E}\right)$, Saptari district of Province no. 2, eastern Nepal covering the area of 143.33 sq. km with 63556 of total population. Saptari is rich with fresh water resources having highest number of ponds covering 9397 ha and with the surface area 4055 ha. (Budhathoki and Sapkota, 2018) (fig. 1a and 1b). The collected fishes were brought to Department of Zoology, Post Graduate Campus, Biratnagar, Tribhuvan University for examination and identification of helminth parasites. 


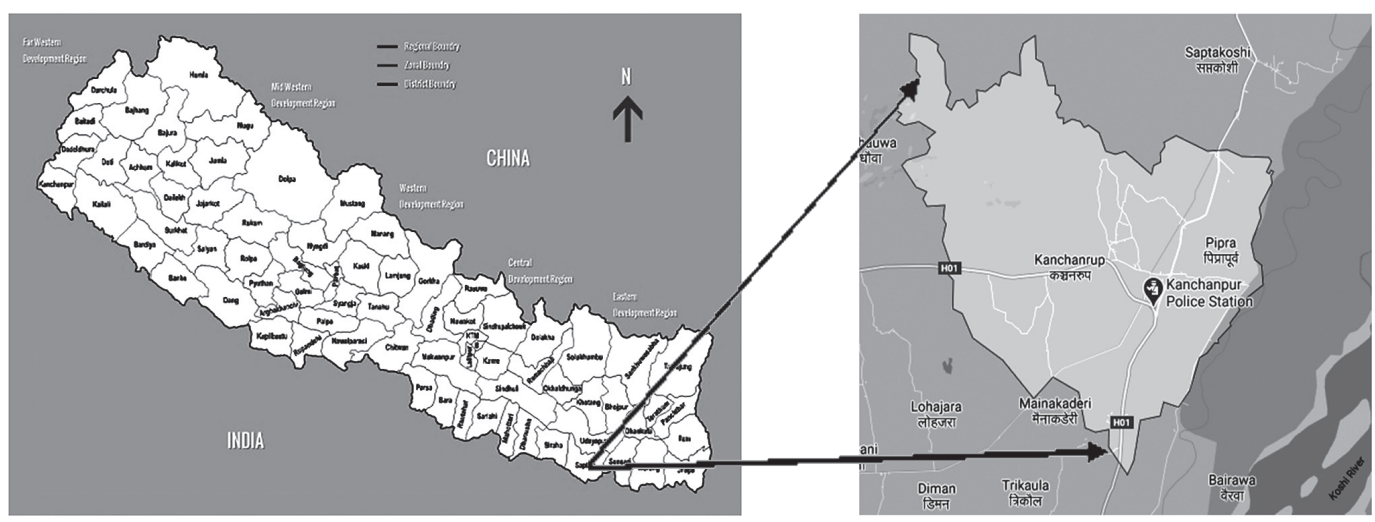

Fig. 1. a) Map of Nepal showing Saptari district.
Fig. 1 b) A map of Kanchanrup

showing study sites.

\section{MATERIALS AND METHODS}

\section{Specimen collection}

The snakehead fishes (Channa orientalis and C. striatus) were collected from fish markets of Kanchanrup municipality and surrounding rivers( Sundari and Paudaha) and ponds with the help of local fishermen from May 2017 to April 2018. After proper washed they were carried to Zoology department of Post Graduate Campus, Biratnagar for examination and identification of helminth parasites. The fishes were dissected to separate the gastro-intestine from the visceral mass of the body. The tracts were kept in petri dish. Then it was cut into pieces, each of one centimeter for observation of helminthes parasites. The cut parts were placed in petri dishes containing saline water. The gut contains were further examined under microscope by simple wet mount preparation for search of various helminthes. The remaining gut content was preserved in vials with formalin. The external and internal morphological characters of each worm were recorded and identified by using standard keys. Data were analyzed using statistical package for the social science (SPSS) version 16.0 and interpreted according to frequency distribution and percentage. Data were recorded regarding the prevalence of helminth parasites in two snakehead fishes. The prevalence of helminth parasites was calculated according to Margolis et al. (1982), where, prevalence (p) = the number of infected host with one or more individuals of a particular parasites species divided by number of hosts examined (expressed in percentage). 


\section{RESULTS AND DISCUSSION}

The snakehead fishes were studied for gastro-helminth parasites which involved $C$. orientalis $(\mathrm{n}=200)$ and $C$. striatus $(\mathrm{n}=225)$. Out of 425 fish examined, 367 fishes were found to be infected. C. orientalis was infected by nematodes, trematodes and cestodes. Similarly, C. striatus was infected by nematodes, cestodes and acanthacephalan (table 1).

Table 1. Infection of Channa species with gastrointestinal helminth parasites.

\begin{tabular}{|l|c|c|c|c|}
\hline \multirow{2}{*}{ Fish species } & \multicolumn{4}{|c|}{ Group of helminth parasites detected } \\
\cline { 2 - 5 } & Nematode & Trematode & Cestode & Acanthacephalan \\
\hline Channa orientalis & + & + & + & - \\
\hline Channa striatus & + & - & + & + \\
\hline+ (present); - (absent)
\end{tabular}

C. orientalis was infected with 4 helminth species giving prevalence of $87.5 \%$. Capillaria pterophylli was observed in 95 fishes $(\mathrm{P}=47.5 \%)$, Gonocerca phycidis in 175 fish specimens ( $\mathrm{p}=87.5 \%)$, G. goppa from 25 fishes ( $\mathrm{p}=12.5 \%)$ and Senga sp. in 11 fishes ( $\mathrm{p}=5.5 \%$ ). The fishes infected by trematodes were 175 (table 2).

Table 2. Prevalence of helminth parasites in Chana orientalis.

\begin{tabular}{|l|l|c|c|}
\hline \multicolumn{1}{|c|}{$\begin{array}{c}\text { Number of fish } \\
\text { examined }\end{array}$} & \multicolumn{1}{|c|}{ Observed parasites } & $\begin{array}{c}\text { Number of fish } \\
\text { infected }\end{array}$ & $\begin{array}{c}\text { Prevalence (P) of } \\
\text { infection }\end{array}$ \\
\hline \multirow{3}{*}{200} & Nematodes & $\mathbf{9 5}$ & $\mathbf{4 7 . 5} \%$ \\
\cline { 2 - 4 } & Capillaria pterophylli & 95 & $47.5 \%$ \\
\cline { 2 - 4 } & Trematodes & $\mathbf{1 7 5}$ & $\mathbf{8 7 . 5} \%$ \\
\cline { 2 - 4 } & Gonocerca physidis & 175 & $87.5 \%$ \\
\cline { 2 - 4 } & Genarchopsis goppo & 25 & $12.5 \%$ \\
\hline \multirow{3}{*}{ Total } & Cestoda & $\mathbf{1 1}$ & $\mathbf{5 . 5 \%}$ \\
\cline { 2 - 4 } & Senga sp. & 11 & $5.5 \%$ \\
\hline & & $\mathbf{1 7 5}$ & $\mathbf{8 7 . 5 \%}$ \\
\hline
\end{tabular}

G. phycidis and C. pterophylli were concurrently detected from 95 fishes. Similarly, G. phycidis andG. Goppo were concurrently detected from 25 fishes. Likewise, $G$. phycidis and Senga sp. from 11 fishes showing total multiple infection number 131(74.9\%) (table 3). 
Table 3. Multiple infections of $\boldsymbol{C}$. orientalis with helminth parasites.

\begin{tabular}{|c|c|c|c|c|c|c|}
\hline $\begin{array}{c}\text { Total } \\
\text { number } \\
\text { of fish } \\
\text { examined }\end{array}$ & $\begin{array}{c}\text { Total } \\
\text { number } \\
\text { of fish } \\
\text { infected }\end{array}$ & $\begin{array}{c}\text { Parasites } \\
\text { observed }\end{array}$ & $\begin{array}{c}\text { Number (\%) of multiple infection with } \\
\text { pterophylli }\end{array}$ & $\begin{array}{c}\text { Nenarchopsis } \\
\text { goppo }\end{array}$ & Senga sp. & $\begin{array}{c}\text { Total } \\
\text { number } \\
\text { (\%) of } \\
\text { multiple } \\
\text { infection }\end{array}$ \\
\cline { 4 - 6 } & 175 & $\begin{array}{c}\text { Gonocerca } \\
\text { phycidis }\end{array}$ & $95(54.3 \%)$ & $25(14.3 \%)$ & $11(6.3 \%)$ & $131(74.9 \%)$ \\
\hline
\end{tabular}

Out of 225, 192 specimens of $C$. striatus was found to be infected with four species of helminth parasites i.e. C. intestinalis from 51 fishes $(\mathrm{p}=22.67 \%)$, Neocamellanus sp. from 8 fishes $(\mathrm{p}=3.55 \%)$, Bothriocephalus sp. from 71 fishes $(\mathrm{p}=31.55 \%)$ and $P$. ophiocephali from 76 fishes ( $\mathrm{p}=33.78 \%$ ) (table 4).

Table 4. Prevalence of helminth parasites in $C$. striatus.

\begin{tabular}{|l|l|c|c|}
\hline \multicolumn{1}{c|}{$\begin{array}{c}\text { Number of fish } \\
\text { examined }\end{array}$} & \multicolumn{1}{|c|}{ Observed parasites } & $\begin{array}{c}\text { Number of fish } \\
\text { infected }\end{array}$ & $\begin{array}{c}\text { Prevalence (p) of } \\
\text { infection }\end{array}$ \\
\hline \multirow{5}{*}{225} & Nematodes & $\mathbf{5 9}$ & $\mathbf{2 6 . 2 2 \%}$ \\
\cline { 2 - 4 } & Camallanus intestinalis & 51 & $22.67 \%$ \\
\cline { 2 - 4 } & Neocamellanus sp. & 8 & $3.55 \%$ \\
\cline { 2 - 4 } & Cestodes & $\mathbf{7 1}$ & $\mathbf{3 1 . 5 5 \%}$ \\
\cline { 2 - 4 } & Bothriocephalus sp. & 71 & $31.55 \%$ \\
\cline { 2 - 4 } & Acanthacephalans & $\mathbf{7 6}$ & $\mathbf{3 3 . 7 8 \%}$ \\
\cline { 2 - 4 } & Pallisentis ophiocephali & $\mathbf{7 6}$ & $33.78 \%$ \\
\hline Total & & $\mathbf{1 9 2}$ & $\mathbf{8 5 . 3 3 \%}$ \\
\hline
\end{tabular}

Channa spp. was heavily loaded with gastro-intestinal parasite with prevalence of $86.35 \%$. The prevalence of helminth parasites in C. orientalis was $87.5 \%$ whereas nematodes, trematodes and cestodes were $47.5 \%, 87.5 \%$ and $5.5 \%$ respectively. One nematode (Capillaria pterophylli), two trematodes (Gonocerca phycidis and Genarchopsis goppo) and one cestode (Senga sp.) were detected in the fishes showing trematodes as more commonly detected parasites than nematodes and cestodes in C. orientalis.

Parasites, an important but often neglected component of any ecosystem, drain off energy at virtually every trophic level within a food web giving diverse effects on hosts. They affect behaviour, reduce fecundity and mass mortality causing great economic loss in aquaculture. Fishes become infected with nematodes if they are fed live foods containing 
infective life stages or if they are raised in culture settings that promote the growth of other animals carrying the infective stages of the nematode (vector or parasitic host) or allow nematodes to complete their life cycle (intermediate hosts). Some nematodes can be transmitted directly from fish to fish (Yanong, 2017). Srivastava (1975) expressed the mass reproduction and very quickly spread of the parasites taken place when environmental conditions such as water, food and temperature become favorable.

In the present study, the snakehead fishes (C. orientalis and C. striatus) were studied for their gastrointestinal helminth parasites. $C$. orientalis was infected by nematode Capillaria pterophylli. It was not found in C. striatus which was infected by two others species of nematode i.e., Camallanus intestinalis and Neocamellanus sp. Similarly, C. striatus was infected by Cestodes Bothriocephalus spp. and Acanthocephalans Pallisentis ophiocephali. Both of them were absent in C. orientalis. It was infected by cestode Senga sp. Likewise, C. orientalis was infected by two species of trematodes i.e. Gonocerca physidis and Genarchopsis goppo but not found in C. striatus. C. orientalis was to be infected with four helminth species i.e.Capillaria pterophylli, Gonocerca phycidis, G. goppa and Senga. The prevalence of infection in trematode was maximum (87.5\%) in Gonocerca physidis. This prevalence of infection by trematode in C. orientalis is near to the result of Mangolsana et al. (2016) who stated that $C$. orientalis were found to be infected with trematodes (Allocreadium fasciatusi and Metaclinostomum srivastavai) having prevalence $79.17 \%$ (19 out of 24). Similarly, Puinyabati et al. (2010) identified two species of trematodes ( $A$. fasciatusi and $A$. handia) from C. orientalis.

The prevalence of helminth parasites in fishes (C. striatus) was $85.33 \%$ having infections by Acanthocephalans (33.78\%), Cestodes (31.55\%) and Nematodes (26.22\%). Four species of helminth parasites were identified from gastro-intestine of $C$. striatus i.e. two nematodes (Camallanus intestinalis and Neocamellanus sp.), one cestode (Bothriocephalus sp.) and one acanthacephalan (Pallisentis ophiocephali). The result is synchronized with finding of Mangolsana et al. (2016), and Kundu \& Bhiyan (2016). Mangolsana et al. (2016) stated the prevalence of infection was $86.67 \%$ for C. striatus. Kundu \& Bhuiyan (2016) reported four different helminth parasites from C. striatus i.e. Pallisentis ophiocephali, Camallanus intestinalus, Ascaridia sp. and Bothriocephalus cuspidatus. Also, 100\% fish were infected by Acanthocephalans (Ningthoukhongjam et al., 2015). The difference in types of parasites in the present study may be due to geological variation (water pollution, temperature fluctuation, the absence of suitable foods, low oxygen dissolves, etc.) and number of fish specimen included in the study. Air breathing fishes are infected by nematodes, cestodes, trematodes and acanthocephalans 
as reported by other previous workers like Bhure, 2008. The presence of parasites up to a large extent are dangerous to fish production. They produce disease condition in fish thereby increasing their susceptibility to other diseases, causing nutritive devaluation of fish and fish loss and finally reduced the fish productivity in aquaculture. The parasitic diseases, either alone or in conjunction with other environmental stresses, may influence weight and reproduction of the host, alter its population characteristics or affects its economic importance. The common clinical signs occur due to nematode (adult and larvae) infection include haemorrhage, inflammation, adhesions, oedema, necrosis, encapsulation, granuloma formation, atrophy, ulceration, degeneration, erosion of the layer of the intestine and stomach. The adult is the inhabitant of the intestine in fishes as suggested by Das (2015) and Ranibala et al. (2013).Nematodes utilize the predatory fishes like Channa sp. as intermediate or temporary hosts and can infect all organs of their hosts with heavier infections as suggested by Paperna (1996b).

Channa sp. is heavily loaded by gastro-intestinal helminth parasites might be the result of poor water quality, crowding and absentees of favorable foods enhancing suitable habitats for those parasites. The hazard of multiple and simultaneous infection of helminth may give rise to a health threat of zoonotic transmission to consumers. The parasitic infections to fishes influence their productivity, marketability and death of fishes resulting great loss to fish farmers. Therefore, immediate development of effective control measures and an application of good nourishment practice are necessary to lower the helminthes infection to fishes.

\section{ACKNOWLEDGEMENTS}

The authors would like to give sincere gratitude to Dr. Bharat Raj Subba Post Graduate Campus, Tribhuvan University, Biratnagar, who constantly encouraged and inspired us for this work. We would like thank to fisherman Jageshor Majhi who helped to collect the fishes.

\section{REFERENCES}

Bhure, D B (2008) Faunal Diversity of Helminth Parasites of Freshwater Fishes from Maharashtra State, India. Ph.D. Thesis, Dr. Babasaheb Ambedkar Marathwada University, Aurangabad, India.

Budhathoki, R; SAPкota, B (2018) Fish Farming in Nepal: Trend and Consumption Level. Acta Scientific Agriculture 2(9):109-115.

Chowdhury, S Z; Hossain, M M (2015) Isolation and Characterization of Internal Parasites in Snakehead. International Journal of Fisheries and Aquatic Studies 2(4): 17-22. 
DAs, D (2015) "Helminth Parasites in Some Selected Fishes of Order Perciformes in Three Wetlands of Goalpara District, Assam." Ph.D. thesis, Gauhati University, Assam, India.

EISSA, I A M (2002) Parasitic fish infections in Egypt. In Dar El-Nahda El Arabia Publishing, Cairo, Egypt; pp 52 - 53. ( $1^{\text {st }}$ edition).

Farzana, N; Naher, J; Zafar, M A; Chandra, K J; Ahmed, G U (2019) Study on infestations and biodiversity of metazoan parasites in Channa punctatus (Bloch), Mymensingh region. Journal of Bangladesh Agricultural University 17 (3): 409-416.

Gautam, N K; Misra, P K; Saxena, A M (2018) Seasonal Variation in Helminth Parasites of Snakeheads Channa punctatus and Channa striatus (Perciformes: Channidae) in Uttar Pradesh, India. Helminthologia 55:230-239.

GuPTA, R (1996) Effects of Lengths (=Age) of Heteropneustes fossilis on the abundance of two Parasites. Tribhuvan University Journal 19(2): 83-87.

Gupta, N; Gupta, D K; Singhal, P (2016) Description of Pallisentis (Brevitritospinus) punctati n. sp. (Acanthocephala: Quadrigyridae) from Channa punctatus in Bareilly, Uttar Pradesh, India. Iran J. Parasitol. 10(4): 605-616.

Khalil, L F; Polling, L (1997) Checklist of the helminth parasites of African freshwater fishes. University of the North, Republic of South Africa. River Printers, Pieterburg, South Africa; 185 pp.

Khanal, B (2003) Ecological study of helminth parasites in fishes. Our Nature 1: 67-68.

Khurshid, I; AHMAD, F (2012) Gastro-intestinal helminth infection in fishes relative to season from Shallabugh wetland. International Journal of Recent Scientific Research 3(4): $270-72$.

Kundu, S; BhuIYAN, A L (2016). Abundance of helminth parasite in Channa striatus (Bloch, 1793) from Punarbhaba and Atrai Rivers. Dhaka Univ. J. Biol. Sci. 25(1): 39-46.

LuQue, J L; Poulin, R (2004) Use of fish as intermediate hosts by helminth parasites: a comparative analysis. Acta Parasitologica 49: 353-6.

Mangolsana, K; Romen, N; Indira, N; Bijayalakshmi, C (2016) Diversity of helminth parasite of food fishes of Ikop Lake, Thoubal District, Manipur India. International Journal of Current Research 8(3): 27323-28.

Margolis, L; Esch, G W; Holmes, J C; Kuris, A M; Schad, G A (1982) The use of ecological terms in parasitology (Report of an Ad Hoc Committee of the American Society of Parasitologists). Journal of Parasitology 68:131-33. 
MARKov, GS(1961)Physiology offishparasites. InDOGIEL, V.A.,PETRUSHEVESKY, G K POLYANSKY, YU I (Eds) Parasitology of Fishes. Edinburg and London 1961: Oliver and Boyd Ltd. UK; pp 117-139.

Ningthoukhonguam, I; Ngasepam, RS; Chabungbam, B; Shomorendra, M (2015) Helminth parasites infection of the fishes of Nambol locality, Bishnupur District, Manipur. International Journal of Current Research 7(1): 11299-11302.

PAPerna, I (1996) "Nematodes" In Parasites, Infection and Diseases of Fishes in Africa-An update. CIFA Technical Paper No. 31. Food and Agriculture Organization, Rome, Italy; $220 \mathrm{p}$.

Puinyabati, H; Shomorendra, M; Kar, D (2010) "Studies on trematode parasites of air breathing fishes of Awangsoi Lake. Journal of Applied and Natural Science 2(2): 242-44.

Ranibala, T; Shomorendra, M; Kar, D (2013) Seasonal variation of the nematode Camallanus anabantis in the Fish Anabas testudineus in Loktak Lake, Manipur, India. Journal of Applied and Natural Science 5(2): 397-399.

RoHDE, K (1993) Ecology of marine parasites: an introduction to marine parasitology. CAB International, Wallingford, UK; 298 p. ( $2^{\text {nd }}$ edition).

SHARMA, R (2012) Investigations on helminth parasites of freshwater fish fauna of Muzaffarnagar. Ph.D. Thesis, Chaudhary Charan Singh University, Meerut, India.

SrivastaVa, C B (1975) Fish pathological studies in India: a brief review. Dr. B.S. Chouhan Comm. Fish Pathological Studies in India: A Brief Review. Dr. B.S. Chouhan Comm., pp 349-358.

Singha, R; Shomorendra, M; Kar, D (2015) Parasite infection of three freshwater fishes in Dolu Lake, Silchar, Assam. International Journal of Fisheries and Aquatic Studies 2(3): 125-27.

YADAV, S N (2017) Study on helminth parasites of some fresh water fishes. International Journal of Zoology Studies 2(2): 50-52.

YANONG, R P E (2017) Nematode (Roundworm) infection of fish. IFAS Extension, University of Florida, USA, pp 1-9. 